\title{
APLIKASI FABRIKASI DIGITAL ARSITEKTUR STUDI DESAIN PARAMETRIK DIAGRAM VORONOI
}

\author{
Hendro Trieddiantoro Putro ${ }^{1,}{ }^{*}$, Wiliarto Wirasmoyo ${ }^{2}$, \\ 1 Jurusan Arsitektur, Fakultas Sains dan Teknologi, Universitas Teknologi Yogyakarta, \\ 2Jurusan Arsitektur, Fakultas Sains dan Teknologi, Universitas Teknologi Yogyakarta, \\ *Hendro.trieddiantoro@gmail.com
}

Diterima: 9 April 2019

Direvisi: 27 Mei 2019

Disetujui: 16 Juni 2019

ABSTRAK. Perkembangan teknologi dan metode desain di arsitektur terus berlanjut, misalnya metode desain parametrik dan penerapan teknologi fabrikasi digital untuk menciptakan model representasi dan konstruksi. Fabrikasi digital didefinisikan sebagai proses memanipulasi objek menggunakan mesin perangkat CNC router, $3 \mathrm{~d}$ printer, dan laser cutter melalui metode pengurangan atau penambahan. Mempelajari teknologi fabrikasi digital saat ini menjadi tuntutan bagi pelaku akademis dan profesi di bidang arsitektur. Baik pengajar dan mahasiswa arsitektur kini dituntut untuk meningkatkan pemahaman serta kemampuan dalam mengolah desain digital menjadi representasi model yang berskala melalui proses fabrikasi digital.

Melalui penelitian ini, peneliti akan menjabarkan proses pembelajaran dari aplikasi fabrikasi digital laser cut dengan menggunakan metode desain parametrik, yaitu berupa pengembangan desain berbasis diagram Voronoi. Pengembangan desain parametrik akan dilakukan dengan menggunakan software Rhino dengan Grasshopper. Kegiatan penelitian ini dilakukan di Jurusan Arsitektur FST Kampus 2 Universitas Teknologi Yogyakarta. Penelitian ini terbagi menjadi beberapa kegiatan, yaitu proses desain digital, proses persiapan fabrikasi, dan pemasangan atau perakitan model. Selain itu, peneliti akan menjelaskan hambatan atau permasalahan yang dihadapi di setiap kegiatan, serta peluang dan tantangan dari aplikasi fabrikasi digital di arsitektur. Hasil penelitian menunjukkan proses yang jelas di setiap fase kegiatan, penjelasan dilengkapi dengan hambatan atau masalah yang dihadapi serta penyelesaian permasalahan. Kegagalan yang terjadi pada proses fabrikasi memberikan pembelajaran bahwa desain digital dan fabrikasi digital merupakan satu kesatuan proses yang saling berhubungan. Peluang serta tantangan dari aplikasi fabrikasi digital di dunia arsitektur ini selanjutnya menjadi pertimbangan yang menarik untuk dibahas.

Kata kunci: Fabrikasi Digital, Laser Cut, Metode Desain Parametrik, Diagram Voronoi, Rhino dengan Grasshopper

ABSTRACT. The development of technology and design methods in architecture continues, for example, parametric design methods and the application of digital fabrication technology to create models of representation and construction. Digital fabrication defined the process of manipulating objects using a CNC router, $3 d$ printer, and laser cutter using a reduction or addition method. Studying digital fabrication technology is now a demand for academics and professionals in the field of architecture. Both architecture instructors and students are now required to increase their understanding and ability to process digital designs into scale-scale representation through a digital fabrication process.

Through this research, researchers will describe the learning process of digital laser cut fabrication applications using parametric design methods, which are in the form of developing a Voronoi diagram- based design. Parametric design development was carried out using Rhino software with Grasshopper. This research activity was completed in the Department of Architecture FST Campus 2, University Technology of Yogyakarta. This research divided into several steps, namely the digital design process, the fabrication preparation process, and the installation or assembly of the model. Also, researchers will explain the obstacles or problems faced in each activity, as well as the opportunities and challenges of digital fabrication applications in architecture. The results of the study showed a transparent process in each phase of the activity, and the explanation complemented by obstacles or problems encountered and problem-solving. Failures that occur in the fabrication process provide learning that digital design and digital fabrication are a unified, interconnected process. The opportunities and challenges of digital fabrication applications in the architectural world are further interesting considerations to discuss.

Keywords: Digital Fabrication, Laser Cut, Parametric Design Methods, Voronoi diagrams, Rhino with Grasshopper 


\section{PENDAHULUAN}

Sejarah teknologi fabrikasi dimulai dengan produksi massal yang diperkenalkan dan dikembangkan oleh Henry Ford, pendiri Ford Motor Company pada awal abad ke-19 (Hutama, 2013). Metode ini bekerja dengan memproduksi model yang direplikasi. Oleh karena itu, korelasi antara kuantitas, waktu, dan prediksi kualitas secara akurat, dan biaya operasional lebih murah.

Dalam Arsitektur, seperti dalam Pabrikan Digital Teknik Arsitektur Dan Material Lisa Iwamoto yang mana teknologi CAD menggantikan gambar, fabrikasi digital membawa pemahaman baru dan memperluas batas-batas bentuk dan konstruksi arsitektur (Iwamoto, 2009).

Selain itu, Seely menjelaskan bahwa fabrikasi digital memengaruhi proses desain arsitektur karena peran pentingnya mendukung pembuatan model arsitektur (Seely, 2004). Sejalan dengan Seely, Dunn menjelaskan alasan mengapa siswa dan profesi arsitek membuat model. Representasi ide-ide kreatif sangat penting dalam disiplin berbasis desain dan sangat relevan dalam arsitektur di mana kita sering tidak dapat melihat hasilnya, yaitu bangunan yang dibangun, hingga akhir proses desain. Konsep awal dikembangkan melalui proses yang memungkinkan perancang untuk menyelidiki, merevisi, dan selanjutnya memperbaiki gagasan secara rinci yang meningkat sampai pada titik sedemikian rupa sehingga desain proyek siap dibangun. Model dapat menjadi objek yang sangat serbaguna dalam proses ini, memungkinkan desainer untuk mengekspresikan pikiran secara kreatif (Dunn, 2014).

Fabrikasi digital, seperti pada era digital, telah mengisi kesenjangan antara konsepsi dan produksi. Membuat tautan digital langsung melalui proses "file-ke-pabrik" dari pabrikan yang dikontrol secara numerik (CNC) (Kolarevic, 2003). Penggunaan desain digital dan fabrikasi digital untuk mahasiswa arsitektur semakin menjadi keterampilan biasa (Hemsath, 2010).

Paradigma teknologi desain dan fabrikasi digital ini dijelaskan oleh Stoutjesdijkas yaitu era industri 4.0, bertujuan membuat teknik fabrikasi digital tersedia untuk semua orang. Ini adalah pergeseran dari dunia konsumen ke produsen, di mana setiap orang dapat menghasilkan energi, informasi, makanan, dan komoditas, berdasarkan jaringan pengetahuan bersama dan perangkat fabrikasi digital (Stoutjesdijk, 2013).

Penelitian ini bertujuan untuk mempelajari fabrikasi digital, peneliti akan menjabarkan proses pembelajaran aplikasi fabrikasi digital laser cut dengan menggunakan metode desain parametrik berupa pengembangan desain berbasis Voronoi diagram.

\section{Desain Parametrik}

Wassim Jabi dalam bukunya "Desain Parametrik untuk Arsitektur" mengatakan bahwa desain parametrik adalah proses desain berdasarkan pemikiran algoritmik yang memunculkan detail parameter, di mana parameter bersama-sama memperkuat dan memperjelas hubungan antara tujuan desain dan bagaimana desain akan merespons untuk masalah (Jabi, 2013).

Desain parametrik adalah konsep yang memungkinkan desainer untuk mendefinisikan hubungan antara elemen atau kelompok elemen, juga menetapkan nilai atau ekspresi untuk mengatur dan mengendalikan definisi tersebut (Dunn, 2012). Dunn menambahkan bahwa proses berlanjut sampai hasil yang diinginkan dipilih berdasarkan kriteria "performatif" dan estetika yang relevan. Untuk yang tidak berpengalaman, proses desain parametrik awalnya sangat memakan waktu. Namun, itu tergantung pada kemauan untuk belajar (Woodbury, 2010).

\section{Fabrikasi Digital di Arsitektur}

Pada awal 2000-an, harga dari peralatan prototyping, seperti pemotong laser dan printer 3D turun drastis, dan perangkat Open Source semakin mempopulerkan teknologi ini. Teknologi fabrikasi digital menjadi lebih baik dan lebih mudah diakses, dan aktivitas intelektual yang dimungkinkan oleh teknologi baru menjadi lebih dihargai dan penting. Desainer industri dapat membuat prototipe dalam hitungan hari, bukan bulan (Blikstein, 2013)

Ada definisi yang cukup besar tentang fabrikasi digital, yaitu proses yang dimulai dengan desain digital dan berakhir dengan output dari mesin fabrikasi. Fabrikasi digital adalah paradigma pendidikan dan aktivitas di mana mengaplikasikan pengetahuan multidisiplin untuk menggabungkan desain $2 \mathrm{D}$, desain $3 \mathrm{D}$, penggunaan alat dan mesin. 
Fabrikasi digital berasal dari CAD (Computeraided design) kemudian ditransfer ke perangkat lunak CAM (Computer-aided manufacturing). Output dari CAM siap untuk difabrikasi ke mesin tertentu, seperti printer $3 \mathrm{D}$, laser cut atau mesin CNC.

Laboratorium fabrikasi digital pertama di sekolah-sekolah arsitektur muncul di akhir 90an, dan lab itu adalah hasil dari kolaborasi dengan laboratorium teknik mesin (Celani, 2012). Rapid prototyping dan router CNC adalah mesin pertama untuk membuat model dalam arsitektur. Pada tahun-tahun berikutnya, teknik dan strategi berkembang pesat. Terutama ada 3 langkah untuk pekerjaan fabrikasi digital (Formlabs, 2019), yaitu:

1. Fase desain digital. Langkah pertama ini adalah membuat model virtual menggunakan perangkat lunak CAD. Model 3d diekspor sebagai permukaan.

2. Fase Persiapan Fabrikasi. Langkah untuk mengatur parameter manufaktur dan khusus untuk fabrikasi, menghasilkan file CAM kemudian mengirim ke mesin.

3. Proses fabrikasi. Alat fabrikasi memproduksi komponen berdasarkan data CAM, dengan sedikit atau tanpa bantuan manusia atau interaksi. Merakit bagian- bagian hasil fabrikasi mungkin perlu dilakukan sebelum produk siap digunakan.

Fokus dari fase fabrikasi (Smit, 2016):

- Eksternalisasi ide dan konsep menjadi maket, prototipe, dan produk.

- Pilih bahan analog dan digital untuk mengubah ide menjadi prototipe dan produk.

- Bekerja secara kreatif dan eksploratif untuk membangun dengan berbagai teknologi fabrikasi.

- Memvisualisasikan dan mewakili artefak dengan berbagai cara.

Tercatat pada 10 tahun terakhir ini, teknologi fabrikasi sangat cepat meningkat di dunia institusi akademis. Tercatat di tahun 2016 lebih dari 30 lab fabrikasi arsitektur di Eropa. Alasan utama dari pesatnya perkembangan fabrikasi adalah karena potensi dari industri fabrikasi yang dapat digunakan berbagai tugas seperti studi bentuk. Tantangan dari pembelajaran fabrikasi digital adalah pada membangun hubungan dari CAD dan mesin robotic fabrikasi untuk tugas yang lebih rumit (Blikstein, 2013).

\section{Teknik Laser Cutting}

Pemotong laser adalah mesin yang menggunakan laser untuk memotong bahan seperti papan chip, papan matte, felt, kayu, dan akrilik hingga ketebalan $3 / 8$ inci $(1 \mathrm{~cm})$. Pemotong laser sering dibundel dengan perangkat lunak yang menafsirkan gambar vektor yang dihasilkan oleh sejumlah platform CAD. Pemotong laser mampu memodulasi kecepatan kepala laser, serta intensitas dan resolusi sinar laser, dan dengan demikian mampu memotong dan mencetak materi, serta mendekati grafik raster. Benda-benda yang dipotong dari bahan dapat digunakan dalam pembuatan model fisik, yang hanya membutuhkan perakitan bagian-bagian.

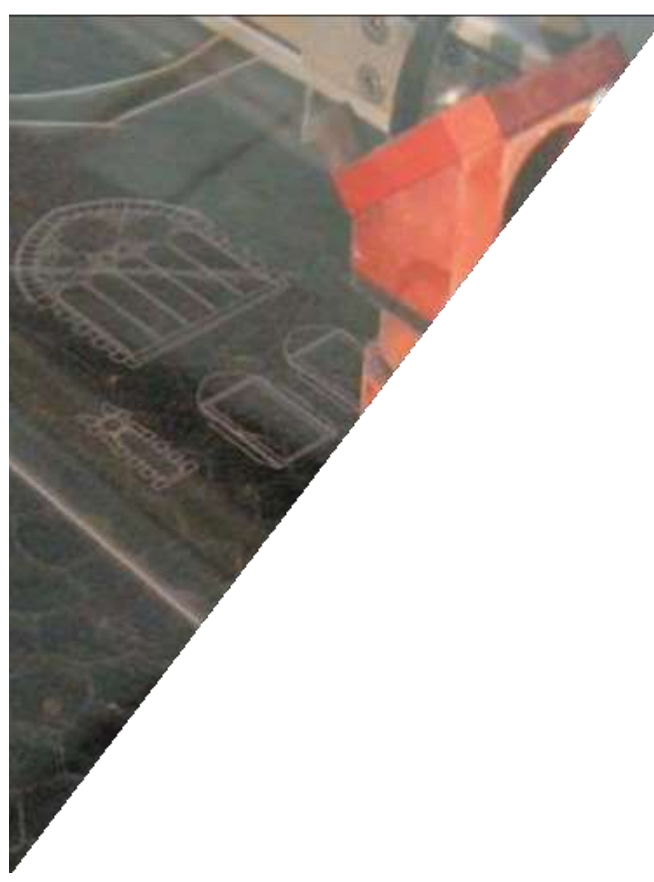

Gambar 1. Laser Cutter sedang Beroperasi Memotong Acrylic (Sumber : Dunn, 2014)

\section{Voronoi Diagram}

Dalam matematika, diagram Voronoi adalah pembagian sebuah bidang menjadi beberapa bagian berdasarkan titik pusat. Setiap titik menjadi korelasi munculnya bidang area, area inilah yang disebut Voronoi cells. 


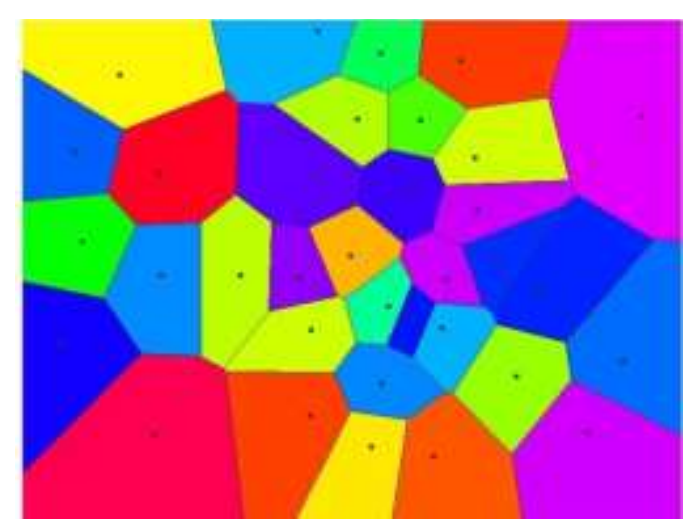

Gambar 2. Voronoi Cells yang terbentuk dari 20 titik (Sumber : Balu Erti, 2015)

\section{METODE PENELITIAN}

Metode penelitian ini adalah penerapan aplikasi fabrikasi digital. Yaitu teknik fabrikasi digital laser cut yang dilakukan dalam beberapa langkah, antara lain fase desain digital, fase persiapan dan proses fabrikasi, serta proses pemasangan. Lokasi penelitian adalah Kampus 2 Universitas Teknologi Yogyakarta.

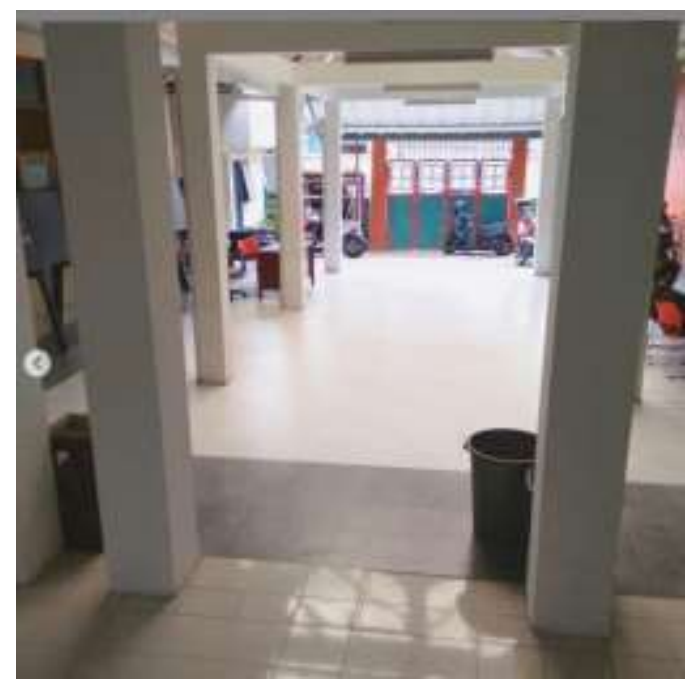

Gambar 3. Lokasi Penelitian Kampus 2 Universitas Teknologi Yogyakarta

(Sumber: Dokumentasi Peneliti, 2019)

Gambar 3 merupakan selasar kampus 2 UTY, di lokasi tersebut peneliti akan mengembangkan Voronoi diagram dengan metode desain parametrik. Pertama, sebelum mengembangkan desain perlu merekonstruksi eksisting menggunakan Rhino dengan Grasshopper. Parameter yang digunakan untuk membuat model 3d eksisting selasar kampus 2 terdiri dari ukuran kolom, jarak kolom, dan tinggi kolom.

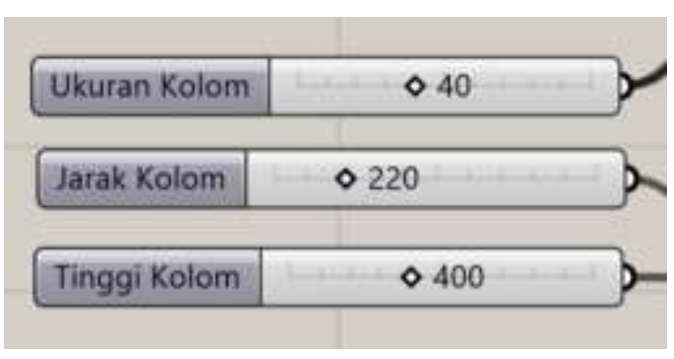

Gambar 4. Parameter 3d model eksisting selasar kampus 2 UTY

(Sumber: Dokumentasi Peneliti, 2019)

Parameter ukuran kolom, jarak kolom, dan tinggi kolom di grasshopper dibentuk dari komponen number slider dengan satuan $\mathrm{cm}$, secara urut diisi 40 untuk ukuran kolom, 220 untuk jarak kolom, dan 400 untuk tinggi kolom.

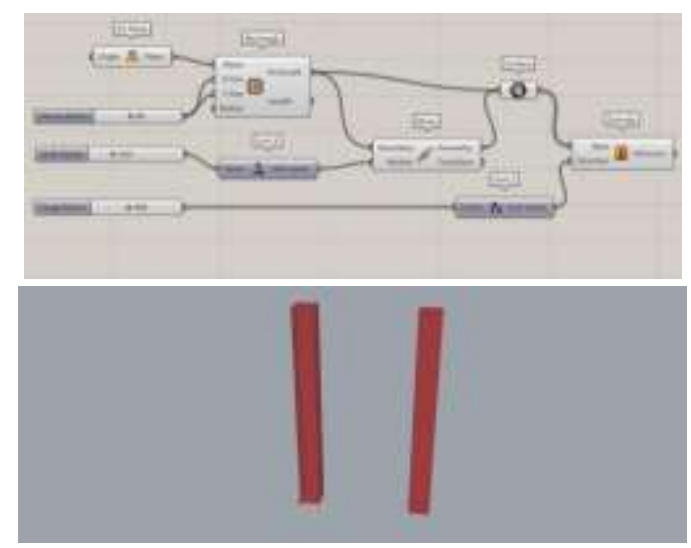

Gambar 5. 3d model kolom eksisting selasar kampus 2 UTY

(Sumber: Dokumentasi Peneliti, 2019)

Gambar 5 merupakan definisi lengkap dari rekonstruksi kolom di grasshopper. Selanjutnya, pengembangan desain Voronoi diagram dilakukan menggunakan metode desain parametrik dengan komponen Voronoi 3D. Komponen Voronoi 3d akan menghasilkan volumetric Voronoi diagram untuk sejumlah titik yang ditentukan. input komponen Voronoi 3D terbagi menjadi 2 parameter, yaitu Points dan Box. Output Voronoi 3D berupa Cells dan Boundary. 


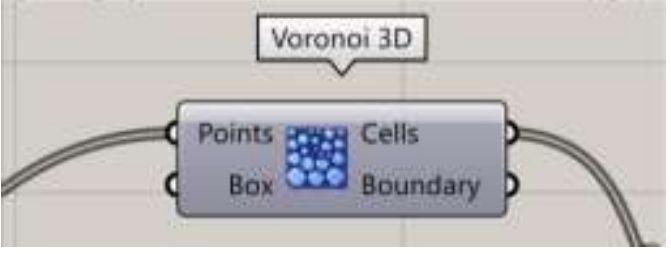

Gambar 6. Komponen Voronoi 3D di Grasshopper (Sumber: Dokumentasi Peneliti, 2019)

Material yang dipilih untuk fabrikasi adalah kertas ivory $300 \mathrm{gr}$ berukuran $110 \mathrm{~cm} \times 80 \mathrm{~cm}$. Perakitan direncanakan menggunakan lem dan klip kertas untuk memudahkan pemasangan.

\section{HASIL DAN PEMBAHASAN}

\section{Fase desain digital}

Proses desain digital menggunakan alat desain parametrik seperti Rhino dengan Grasshopper merupakan cara yang tepat untuk mempersiapkan model $3 d$ untuk fabrikasi. Metode ini juga ditemukan dalam penelitian oleh Agirbas (2015), Stavric et al. (2016), Austern et al. (2018).

Pengembangan desain digital terlihat pada gambar 7, proses dimulai dengan memunculkan sebuah box disela kolom untuk menjadi area persebaran titik sebagai input komponen Voronoi 3D. Ukuran box dengan Panjang $180 \mathrm{~cm}$, lebar $40 \mathrm{~cm}$, dan tinggi $300 \mathrm{~cm}$. Selanjutnya points dimunculkan pada box dengan komponen populate $3 D$, sehingga memunculkan titik di area box dengan jumlah

190. Points dan Box yang dimunculkan kemudian menjadi input untuk komponen Voronoi 3D. Voronoi cells yang muncul sebanyak 190 buah kemudian dikurangi dengan proses seleksi menggunakan komponen curve closest point, sort list, dan sub list. Ketiga komponen tersebut membantu memilih voronoi cells yang hanya berada dekat dengan kurva terpilih. Sehingga menciptakan Voronoi 3D berupa Closed Brep sebanyak 20 buah.

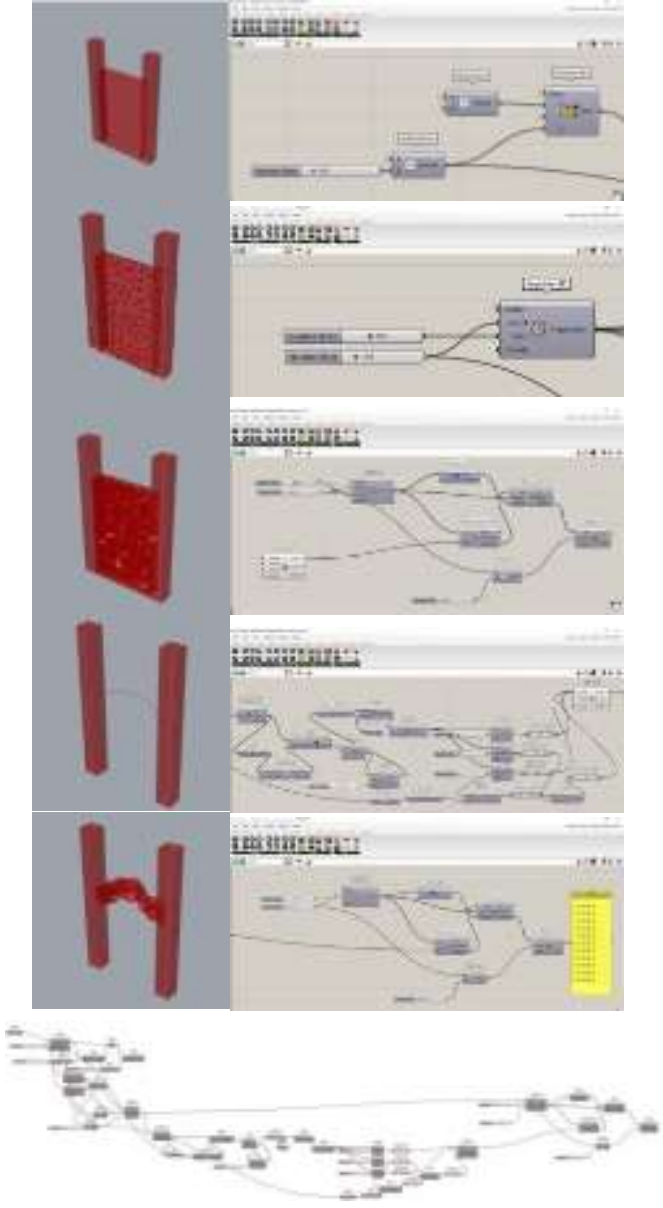

Gambar 7. Proses Pengembangan Desain Digital (Sumber: Dokumentasi Peneliti, 2019)

Dua Puluh (20) buah Closed Brep Voronoi 3D yang sudah terbentuk, kemudian dilubangi dengan komponen surface split di setiap sisinya. Ukuran lubang dibentuk dengan skala 0,65 yang diambil dari ukuran setiap permukaan Voronoi 3D, serta fillet dengan input radius 8 , seperti terlihat pada gambar 8 .

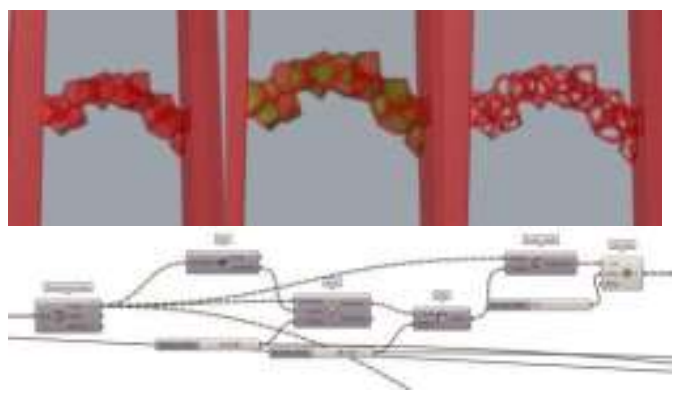

Gambar 8. Proses melubangi sisi Voronoi dengan komponen surface split

(Sumber: Dokumentasi Peneliti, 2019)

Tantangan yang dialami pada penelitian ini untuk fase desain digital adalah waktu yang 
dibutuhkan cukup banyak untuk mengeksplorasi algoritma seperti yang diinginkan, hingga akhirnya dapat memicu pembelajaran (Woodbury, 2010)

\section{Fase Persiapan dan Proses Fabrikasi}

Proses persiapan file untuk fabrikasi dilakukan dengan merubah orientasi permukaan. Permasalahan yang paling sering terjadi ketika persiapan file fabrikasi adalah pada proses reorientasi objek, yaitu reorientasi objek $3 d$ menjadi bidang $X$ dan $Y$, kemudian lebih memakan waktu ketika mengubah orientasi permukaan secara manual atau satu per satu. Namun pada fase ini, peneliti melakukan reorientasi bidang permukaan di grasshopper dengan menggunakan komponen orient. Proses orientasi merubah sebanyak 220 buah permukaan menempel pada bidang koordinat $X Y$ secara instan dengan jarak dan jumlah yang dapat diatur dengan number slider seperti terlihat pada gambar 9 .

Setelah permukaan Voronoi berhasil dirubah orientasinya menjadi bidang $\mathrm{XY}$, peneliti kemudian membuat area tambahan menggunakan algoritma di grasshopper sebagai area untuk menempel. Selanjutnya di setiap permukaan diberi nomor untuk membantu proses merangkai. Proses penomoran permukaan dapat dilakukan di grasshopper, namun karena nomor ini tidak dapat terekspor di Corel, maka perlu dilakukan penomoran ulang secara manual di Corel Draw serta penyusunan objek disesuaikan dengan ukuran media Ivory $300 \mathrm{gr}$ yaitu sebesar $110 \mathrm{~cm} \times 80 \mathrm{~cm}$. Proses penomoran dan penyusunan objek di Corel Draw menghasilkan 19 lembar kertas ivory berukuran $110 \mathrm{~cm} \times 80 \mathrm{~cm}$ berisi permukaan Voronoi siap untuk proses fabrikasi. Ketika penyusunan objek di Corel Draw, warna garis disesuaikan menjadi 2 jenis warna, yaitu warna merah potong dan warna biru untuk grafir seperti terlihat pada gambar 9 . Kegiatan ini memberikan pembelajaran, yaitu peneliti tidak lagi hanya sebagai pengguna alat-alat manufaktur, tetapi juga secara aktif terlibat dalam menyesuaikan media sesuai dengan alat-alat fabrikasi (Blikstein, 2013).
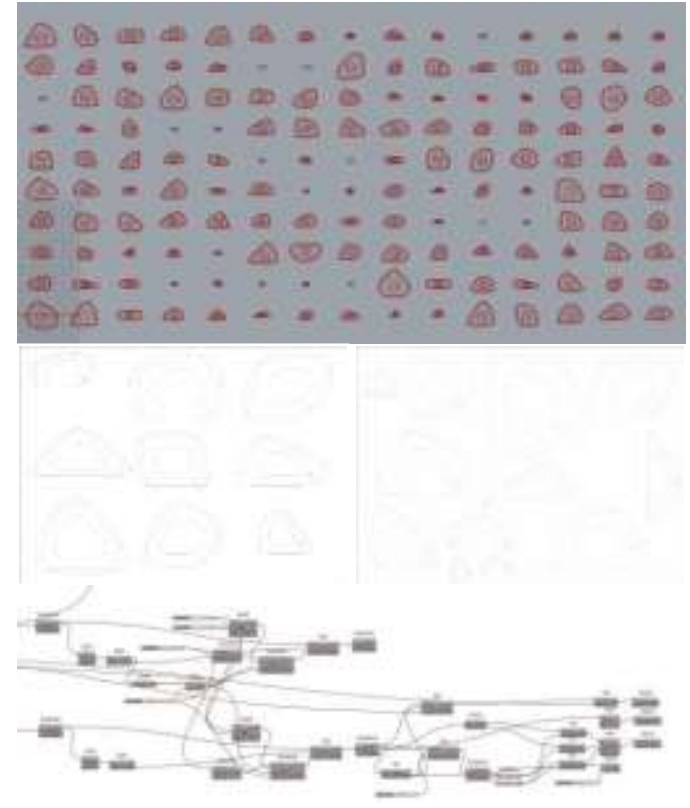

Gambar 9. Proses Orient permukaan menjadi bidang $X Y$ dan Penomoran di Corel Draw (Sumber: Dokumentasi Peneliti, 2019)

Penomoran ulang secara manual di Corel Draw memunculkan permasalahan. Permasalahan tersebut terjadi karena banyaknya objek yang harus diberi nomor secara manual, sehingga memunculkan kurangnya ketelitian penomoran Voronoi untuk laser cut, permukaan Voronoi yang dihasilkan dari proses laser cut menjadi tidak lengkap. Hal ini disadari oleh peneliti ketika proses pengecekan kelengkapan objek sebelum proses perakitan, objek laser cut yang seharusnya 220 buah permukaan atau 20 voronoi 3D. Sehingga peneliti harus melakukan proses penomoran ulang dan laser cut untuk permukaan yang dibutuhkan.

\section{Fase Perakitan}

Peneliti sudah menyiapkan definisi di grasshopper sebagai gambar acuan untuk membantu proses perakitan. Melalui definisi tersebut peneliti bisa mengetahui nomor permukaan yang dibutuhkan untuk merangkai Voronoi 3D, seperti terlihat pada gambar 10. Melalui gambar 10 peneliti bisa mengatakan bahwa untuk merangkai Voronoi 3D nomor 18 membutuhkan objek hasil laser cut dengan nomor 203 sampai dengan 209. 


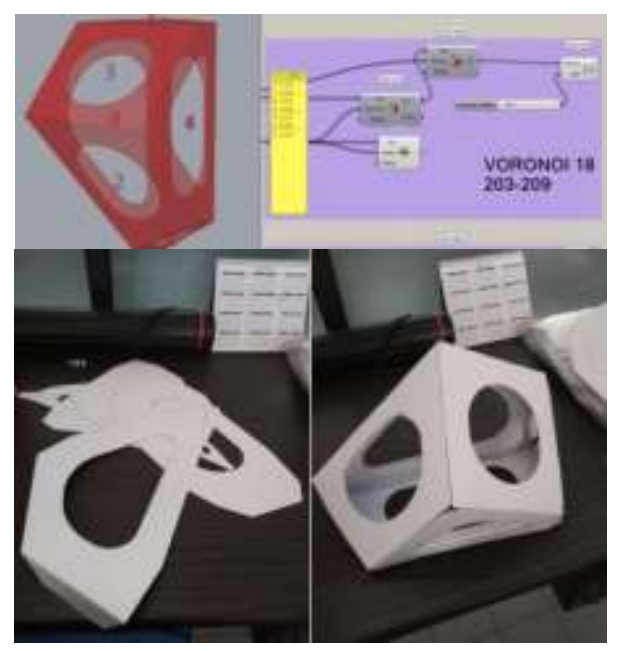

Gambar 10. Definisi di Grasshopper untuk membantu proses perakitan Voronoi 3D (Sumber: Dokumentasi Peneliti, 2019)

Total keseluruhan terdapat 20 buah Voronoi 3D yang dirangkai menggunakan bantuan lem dan klip kertas, seperti terlihat pada gambar 11.

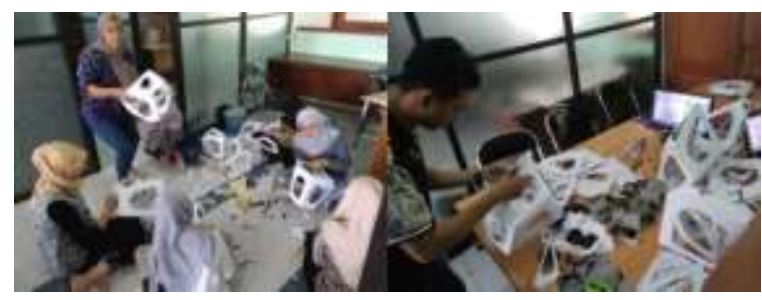

Gambar 11. Proses Perakitan 20 Voronoi 3D

(Sumber: Dokumentasi Peneliti, 2019)

Pada fase perakitan, masalah yang sering muncul adalah kesulitan untuk menyesuaikan bentuk asli Voronoi, misalnya terbalik menempel kertas permukaan hasil laser cut dan juga kesulitan untuk menempel objek yang berukuran kecil, Sehingga tidak jarang terjadi kegiatan melepas kemudian menempel kembali permukaan Voronoi yang sudah tertempel karena setelah dievaluasi, bentuk hasil kegiatan menempel atau merangkai tidak sesuai dengan gambar acuan. Hal itu mengurangi kerapian dari menambah waktu perakitan Voronoi 3D.

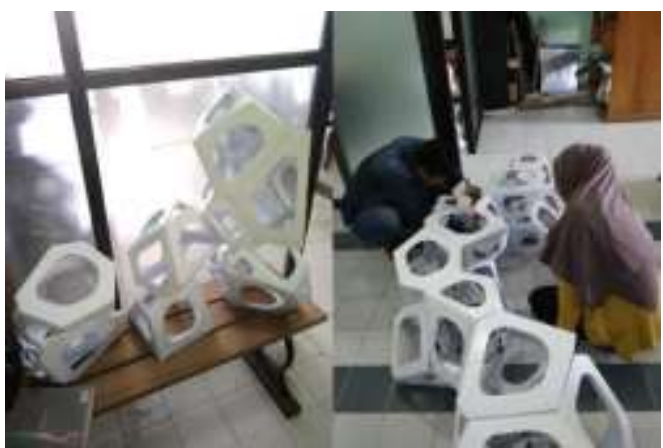

Gambar 12. Proses Perakitan Voronoi 3D (Sumber: Dokumentasi Peneliti, 2019)

Setelah semua Voronoi 3D terpasang, kemudian instalasi diletakkan di selasar menggunakan double tape sesuai dengan rancangan desain, seperti terlihat pada gambar 13.

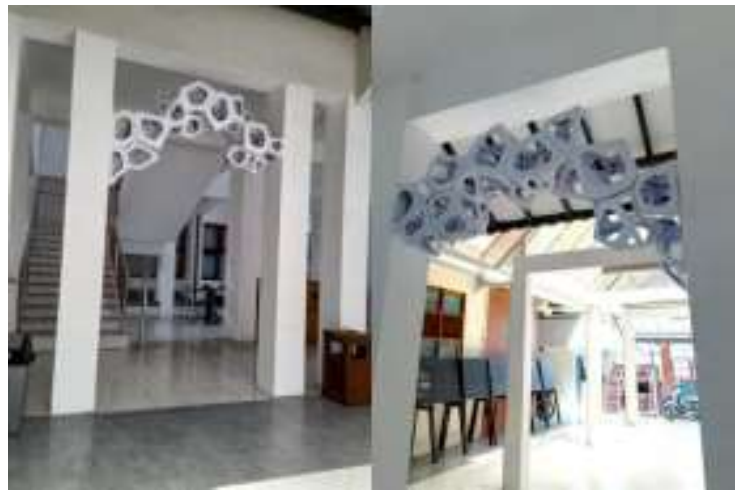

Gambar 13. Proses Pemasangan Voronoi 3D di Selasar

(Sumber: Dokumentasi Peneliti, 2019)

Proses desain digital dan fabrikasi digital membutuhkan pemahaman serta ketepatan dalam sains dan matematika, hal ini juga membutuhkan percobaan serta ketekunan (Nemorin, 2016).

Kegiatan mempelajari fabrikasi digital bisa saja menjadi tantangan yang baru di arsitektur terutama budaya ketukangan, seperti kata Marshall McLuhan, "We become what we behold. We shape our tools and then our tools shape us." ("Media: McLuhan's Message," 2003), yang berarti kita terbentuk dari apa yang kita lihat, kita membentuk alat dan kemudian alat tersebut membentuk kita.

Masalah di bagian persiapan file fabrikasi dan perakitan juga peneliti temukan pada penelitian lain, permasalahan tersebut ditanggapi menggunakan alat desain parametrik seperti 
Rhino dan Grasshopper (Agkathidis, 2019; Baquero et al., 2016)

Peluang dari mempelajari fabrikasi digital adalah kegiatan yang membawa pemahaman baru tentang kemungkinan pembuatan desain yang akan sangat sulit jika dikembangkan menggunakan metode tradisional (Lomker \& Richter, 2018).

\section{KESIMPULAN}

Desain digital dan fabrikasi digital merupakan satu kesatuan proses yang saling berhubungan. Hasil proses desain digital yang baik akan memberikan kemudahan pada proses fabrikasi serta pada proses perakitan atau pemasangan.

Kegiatan mengembangkan desain diagram voronoi dengan metode desain parametrik menjadi salah satu pembelajaran dari aplikasi fabrikasi digital karena desain yang dikembangkan dari parameter dapat diatur secara bersamaan dengan media fabrikasi yang diinginkan, misalnya teknik laser cut dan memunculkan area menempel. Lebih lanjut, proses persiapan file fabrikasi menjadi lebih mudah, terutama proses reorientasi bidang permukaan menjadi bidang XY.

Kegagalan pada proses fabrikasi merupakan hal yang wajar terjadi. Permasalahan yang terjadi pada proses fabrikasi dan perakitan memberikan pembelajaran bahwa ketekunan dan ketelitian merupakan hal yang wajib dimiliki untuk mempelajari fabrikasi digital.

Kegiatan penelitian ini membuka kesempatan bagi para peneliti dan praktisi untuk mengembangkan serta mengeksplorasi desain parametrik, juga mengaplikasikan fabrikasi digital dengan menggunakan teknik $3 d$ printing, laser cut, maupun CNC.

\section{UCAPAN TERIMA KASIH}

Ucapan terimakasih ditujukan kepada Kementerian Riset, Teknologi, dan Badan Riset Inovasi Nasional Republik Indonesia atas dana Hibah Penelitian Dosen Pemula tahun 2019, berdasarkan Surat Keputusan Nomor 7/E/KPT/2019 tanggal 19 Februari 2019 dan no kontrak 111/SP2H/LT/DRPM/2019 tanggal 11 Maret 2019, B/1435.13/L5/R.A.00/2019 tanggal 15 April 2019,12.01/LPPMUTY/K/IV/2019 tanggal 18 April 2019, serta Universitas Teknologi Yogyakarta.

\section{DAFTAR PUSTAKA}

Agirbas, A. (2015). The Use of Digital Fabrication as a Sketching Tool in the Architectural Design Process- A Case Study.

Agkathidis, A. (2019). Dark Matter Garden: A case study in algorithmic modelling and digital fabrication of complex steel structures. Frontiers of Architectural Research.

Austern, G. ... Grobman, J. (2018). Adapting architectural form to digital fabrication constraints. Advances in Architectural Geometry 2018. Gothenburg, Sweden.

Baquero, P. ... Vincent, C. (2016). Simulation and prototyping benefits on digital fabrication. Blucher Design Proceedings Vol 3, Issue 1. SIGraDi 2016, XX Congreso de La Sociedad Iberoamericana de Gráfica Digital 9-11, November 2016, 981-985. Buenos Aires: Argentinapages.

Blikstein, P. (2013). Digital Fabrication and 'Making' in Education: The Democratization of Invention (J. WalterHerrmann \& C. Büching, Ed.). Bielefeld: Transcript Publishers.

Celani, G. (2012). Digital Fabrication Laboratories: Pedagogy and Impacts on Architectural Education. Nexus Netw Journal, 14(3).

Dunn, N. (2012). Digital Fabrication in Architecture. London: Laurence King Publishing Ltd.

Dunn, N. (2014). Architectural Modelmaking (Second Edi). London: Laurence King Publishing Ltd.

Formlabs. (2019). Digital Fabrication 101. Retrieved from https://formlabs.com/blog/digitalfabrication-101/

Hemsath, T. (2010). Searching for Innovation Through Teaching Digital Fabrication. FUTURE CITIES [28th ECAADe Conference Proceedings, 21-30. Zurich (Switzerland).

Hutama, D. (2013). Aspek Konteks Pada Wacana Fabrikasi Arsitektur. Retrieved from https://332lab.wordpress.com/2013/12/1 
8/ Aspek-Konteks-Pada-Wacana-

Fabrikasi- Arsitektur

Iwamoto, L. (2009). Digital Fabrications:

Architectural and Material Techniques.

Princeton Architectural Press.

Jabi, W. (2013). Parametric Design For Architecture. London: Laurence King Publishing Ltd.

Kolarevic, B. (ed. . (2003). Architecture in the Digital Age: Design and Manufacturing. New York: Spon Press.

Lomker, T., \& Richter, K. (2018). Challenges of using Digital Fabrication Techniques for Design Education in Countries with developing educational Level. International Conference The Future of Education Edition 10.

Media: McLuhan's Message. (2003). Retrieved March 26, 2014, from http://www.cyberartsweb.org/cpace/infot ech\%0A/asg/ag6.html\%0A

Nemorin, S. (2016). The frustrations of digital fabrication: an auto/ethnographic exploration of '3D Making' in school. International Journal of Technology and Design Education ISSN 0957-7572.

Seely, J. C. (2004). Digital Fabrication In The Architectural Design Process. Cambridge: Massachusetts Institute of Technology, Department of Architecture.

Smit, R. C. (2016). Towards Digital Smart, Entrepreneurial and Innovative. Pupils have been co-funded under the Erasmus+ program KA 2 - Strategic Partnerships School. Project Number: 2016-1-DK01-KA201-022298. Denmark.

Stavric, M. ... Raković, M. (2016). Digital Fabrication Strategies In Design Education. Conference: 4th ECAADe International Regional Workshop: Between Computational Models and Performative Capacities. NoviS.

Stoutjesdijk, P. (2013). Digital Design and Fabrication for Ultimate Challenges. Delft: TU Delft.

Woodbury, R. (2010). Elements of Parametric Design. Rotledge: Routledge. 
